\title{
Tourist's perceptions in the Liberec region
}

\author{
Helmuth Yesid Arias Gómez', Gabriela Antošová \\ e-mail: hyarias@gmail.com, antosovag@pef.czu.cz \\ ${ }^{1}$ Faculty of Economics and Business, University of Seville, Spain \\ ${ }^{2}$ Department of Humanities, Faculty of Economics and Management, Czech University of Life Sciences \\ Prague, Czech Republic
}

Gómez, H. Y. A., \& Antošová, G. (2014). Tourist's perceptions in the Liberec region. Czech Journal of Tourism, 3(1), 43-61. DOI: 10.2478/cjot-2014-0003.

\begin{abstract}
This paper was elaborated on the basis of a ground work and in the next stage the primary data was processed and analyzed. According to the ground research, this article explores features of cultural rural tourism in the region of Liberec. The perceptions of 500 tourists were examined and their responses were analyzed by a statistical program. The results could be used to improve or promote the tourist services in the selected tourist destinations. Some visitor's preferences were detected in terms of cultural rural activities, natural and rural landscape. In the Liberec region were confirmed the richness of nature, cultural heritage, social life in local communities and their traditions. The correspondence analysis between reasons were made of the visitors responses.
\end{abstract}

\section{Keywords}

Perceptions, tourists, cultural landscape, rural tourism, Liberec region

JEL classification: R11, F63, L83 / Accepted: 30 April 2014 


\section{Introduction}

Tourism is an important topic in human activities, and has huge impacts on human context. In the destinations of the Liberec region these impacts are clearly visible. Here the tourists interact with the local culture and society, natural and rural environment. Hence, it is conventional to consider the impacts of tourism under the headings of socio-cultural, economic and environmental impacts. The cultural rural tourism impacts cannot easily be categorized as solely social, environmental or economic, but tend to have several inter-related dimensions. It should also be noted that much tourism planning and management have a relationship to tourism impacts in these destinations. The attractive tourism places have been included in an increasing offer of tourist services that depend on commoditization of natural and cultural resources in the selected destinations. This research developed in the Liberec region, aimed to explore the tourists' preferences during one year and in order to match the opinion of visitors with some concepts related to general environment of this region.

According to the European commission (2011), the Liberec region is classified as a mixed region. For the purpose of this research, it is worthy to focus on this mixed region because this concept includes also rural areas. The Liberec region is located in the north of the Czech Republic. It has borders with Poland and Germany, and also includes four districts LAU (Local administrative unit) 1 - Česká Lípa, LAU 1 - Liberec, LAU 1 - Jablonec nad Nisou and LAU 1 - Semily. Five landscape protected areas can be found there: the Central Czech mountains, the Jizera mountains, the mountains Lužice, the Czech paradise and Kokořínsko. It also includes eight national nature reserves, eight national nature monuments, 37 natural reserves and 63 natural monuments. Sychrov, Grabštejn and Harrachov are tourism attractive places, mostly visited for their cultural and natural heritage.

The research made a practical stage in which 500 tourists were asked. The Liberec region has a broad variety of tourist attractions. Moreover, this variety attracts visitors of different profiles, preferences and ages. Consequently, each destination could develop a sustainable strategy to attract visitors of different profiles.

\section{Theoretical basis}

Hall, Kirkpatrick, and Mitchell (2005) hyptohesized, if cultural rural tourism wishes to fulfil expectations that can contribute to the rural development process and emerge as an industry of sustainable, attractive of destinations, it must identify and meet the challenges facing it as competition, marketing, cooperation and networking (Scott \& Cooper, 2007).

According to Middleton and Hawkins (1998:85) "Tourism management focuses on ways and means to influence visitor's choices of location, access, timing and product provision, and to develop local understanding and knowledge". The competitive success of destinations is declining, and destinations are losing, what previously had been assumed to be a sustainable market advantage. Some regional environments seem to be more suc- 
cessful in stimulating the economic progress and success than others and the continuous emergence of new competitors means that these destinations must monitor their competitive strategies. Marketing is especially required in a climate where average tourist expenditure is declining and cultural rural tourism is facing some negative publicity issues; including images of environmental degradation and the physical deterioration of some heritage and cultural sites. Marketing is often viewed as a weak link in cultural rural diversification and development processes. But, it can be used to counteract these images, especially in the context of cultural rural tourism. Cultural rural providers seek to develop niche markets for their products, in an attempt that product differentiation will give them an advantage over their competitors, allowing them to increase their market share.

However, in order to be successful, a product differentiation strategy must reach the consumers as a tourist, and this is where successful because marketing is crucial. Market segmentation is another strategy whereby tourism operators may seek to meet particular demands of tourism, for example, dance festivals, folklores, traditional festivals etc. Several studies have used different forms of conjoint analysis (Vriens, 1995) or cluster analysis (Jambu, 1983) to identify market segment characteristics, which can then be used to refine a marketing strategy.

According to Hall, Kirkpatrick, and Mitchell (2005) sustainability per se of cultural rural tourism can be provided insights into such issues as: an awareness of visitors expectations, knowledge of the competition, exploitation of any market advantage or opportunity to develop niche/local products, market segmentation and advertising and promotion strategies, including the use of internet and communication technologies (Fuchs \& Höpken, 2011). All of which, if tackled properly, contribute to regional sustainability (Singhal, McGreal, \& Berry, 2013). The very essence of rural tourism is local cooperation and community involvement through appropriate forms of networking. This cooperation and involvement is arguably one of the most important requirements for the sustainability of cultural rural tourism (Regoli, Vittuari, \& Segrè, 2011). Local community participation and the formation of partnerships that contribute to, and participate in, the development process are the basis building blocks of this process (Long, 2001). In fact, Murphy (1985) had argued that as tourism uses the community resources, the community should be a key player in the process of planning and managing tourism. Heritage or cultural aspects of an area may very well contribute to its uniqueness and provide the opportunity to attract segmented markets. However, to gain the best advantage the local providers, including those supplying accommodation, food and attractions, must work together achieve synergy. In order to be an attractive destination, it must include the three key stakeholders - community, visitors, and tourism enterprises. The beneficial tourists improved performance, and increased the prosperity of destinations (Youell \& Wornell, 2005). In any trip there are likely to be a number of reasons which, when combined, can be considered as the motivational factors for the journey. According Mason (2003) these can be characterized as "push" and "pull" factors. According to the particular tourism context, the nature, extent and significance of particular "push" and "pull” factors will vary. It's linked closely with the psychological model of tourism motiva- 
tion developed by Iso-Aloha (1980), which can presented in two dimensions, "seeking" motives and "escaping" motives (Pearce, 1993). The main criticism of this model is that it only handles two dimensions so it is limited by its level of aggregation (Raybould, Digance, \& McCullough, 1999). According to Ryan (1997) the important area of tourism research understands the behaviour of tourists as a motivation to travel. The numbers of factors are presented by cultural conditioning, social influences, perception and education, and their complex means tourist perceptions, but as classified by Crompton and McKay (1997) motives are the beginning of the decision making process that leads to particular types of behaviour. The main components of a general psychological model of motivation are behaviour or activities, motives and needs, goal satisfactions and feedback (Harrill \& Potts, 2002). Not only do the motivations and expectations of tourists changed, but there is also an important geographical aspect to this. Where tourism experiences are had is in itself subject to variations in demand and supply. The Prosser's model (1998) provides a detailed tourism environment which more effectively represents the inner complexities by relations between destination environment, information, promotion and direction, transportation and communication and as a principal mean in tourism market. In this model the main role is presented by location characteristics, cultural patterning, demands, activity interests, expenditure capability and seasonality. All these factors are cycling to destinations, to attractions or within attractions until destination environment. The attractions, service and facilities, host population and culture are showed interrelationship between them in destination environment. The attractions are meant for tourists to see and do, incentives to travel. The last stage of this cycle holds image and perception, promotion and marketing, guides and signposting, as information and publicity. However this last stage also illustrates the starting point on the whole tourism market. This provides the important "push" and "pull" factor as motivations to travel. On the other hand, it means that tourist's perceptions of a destination are affected by their motivations to go to a destination.

Plog's (1973) and Cohen's (1972) previous theories have been proved and each of them have had different success, but have yet to meet universal acceptance (Mason, 2003). Ryan (1991) had drawn on the basis of the work of Matthieson and Wall (1982), Crompton (1979), and Cohen (1972) and submitted a list of eleven major reasons or motivations for tourism: escape, relaxation, strengthening family bonds, social interaction, sexual opportunity, play, self-fulfillment, wish fulfillment, shopping, educational opportunity and social interaction. These can also be linked to the concept of "push" and "pull” factors. According to Ryan (1991), tourist's perceptions can be based on a combination of reasons. In actual terms, it means that this combination can be changed according to circumstances (Ryan, 1997). A more simplified categorization of the reasons for tourist's travel is provided by Chadwick (1987). He assumed the reasons and motivations for travel fell under three main headings: pleasure (leisure, culture, active sports, visiting friends and relatives), professional (meetings, missions, business, job etc.) and other purposes (study, health and transit). In relation to these different types of tourism-related visits, Prosser (1998) suggested a threefold categorization of visitor motivation: pleasure, business, and visiting friends and relatives. According to the survey on 
the tourist's perceptions it can be designed for destinations in the Czech rural regions located in the Liberec region. The first surveys on enthusiasm and perceptions called the destinations image studies were developed by Hunt (1971) and Mayo (1973).

\section{Methodology}

This research is aimed to find the tourist potential of Liberec region based on the concepts and theories of tourist's perceptions. These findings can be used to design or improve promotion and management of tourism of selected destinations in this region. Some improvement in tourist services will be discussed and suggested in order to promote and sustain the interest of tourism in these destinations of the Liberec region. Conclusions will be pointed out with the purpose of achieving sustainability of tourism potential in selected tourist attraction in this region. During December 2012 - December 2013 semi-structured interviews were held in order to fill a standardized questionnaire of 500 tourists in 42 selected destinations in the Liberec region. Destinations are presented according to the geographical aspects predominantly in LAU 1 - Jablonec nad Nisou (28 \%) and Semily (30 \%), and partly in LAU 1 - Česká Lípa (19 \%) and Liberec (23\%). The ground research was performed during different seasons, summer and winter seasons, and when not, during special events as local festivals, opening of cultural monuments, exhibitions etc. In the Liberec region destinations that are more or less attractive were observed. In order to find a tourism potential for this region, the primary data of the questionnaire was analysed in statistical program SPSS. Some analytical tools were used as correspondence analysis and optimal scaling. Also, a brief analysis of correlation matrix was made.

The questionnaire was meant for tourists over the age of 18 years old. The purpose was to capture the highest quantity of responses; the questionnaires were only filled by tourists. The sample wasn't exactly specified, but in each destination the coverage was at it's maximum potential. In the questionnaire it was compulsory to exclude the residents of each destination. The survey was anonymous and the participants wouldn't be identified in any way. The field research tried to achieve maximum coverage at the moment of interviews, people asked to participate could stay one night more or one night less at place. All participants who fulfilled the conditions (over 18 years old and non-residents) where interviewed independently of the length of the journey.

The main components of the questionnaire covered three parts: tourist's visits in destination, tourist's experiences, and basic demographic details. The questionnaire included some questions asking to individuals to associate their satisfaction or dissatisfaction of experiences with some terms, which later were summarized in the following topics:

- satisfaction as early commoditization (Mitchell \& de Wall, 2009) - rural idyll is still intact, frequency of transport, cultural monuments, landscape "Podkrkonoší", natural environment, sport activities, cultural activities, traditions and customs, tourist services, active approach of local people to tourism, tidy destinations... 
- dissatisfaction as early commoditization (Mitchell \& de Wall, 2009) - investment in commoditization initiated, infrastructure, locality, natural environment, modernization and commercialization, lack of development, unwillingness of local people in tourism, lack of tourist services, developed destruction (Mitchell \& de Wall, 2009) growing numbers of visitors and creating potential out-migration, regional disparity, Gypsy community, developed commoditization (Mitchell \& de Wall, 2009) - growing numbers of visitors and some awareness of negative implications.

The processing of answers was treated in SPSS programme, and a correspondence analysis was performed for former terms. The purpose was to associate the described Positive atmosphere (Atmosphere like) and Negative atmosphere (Atmosphere dislike) topics, between themselves and between the Destinations. Later, a multiple correspondence analysis was applied for nominal questions such as a Gender, Age, Nationality, Reasons of visits and Security of family background.

\section{Results}

According to the responses expressed by tourists, two frequency diagrams were depicted (Figure1 and Figure 2). The first one represents the number of responses in each option of Positive atmosphere (Atmosphere like). It is observed that 166 tourists answered that an important aspect of the atmosphere was the natural environment, while 101 remembered early commoditization as a good concept in atmosphere. Some topics, such as Traditions and customs, Tourist Services and Cultural monuments were mentioned by 66, 57 and 55 tourists respectively. The least remembered aspects by tourists were Sport activities, Landscape and Frequency of transport.

A second frequency diagram was applied to aspects of atmosphere that turned out displeasing for visitors. It's worth noting that a majority of individuals were satisfied with the Destinations included in the research, 343 of them considered that there were no negative aspects in atmosphere (Atmosphere dislike). One thing to mention: it's important to note that 50 visitors expressed that the Infrastructure was a negative aspect. In regard to Developed commoditization, 38 tourists identified it as a negative experience in the destinations. Concepts such as Lack of development and Developed destruction were recognized as deficiencies in 25 and 22 cases, respectively. Locality and Natural environment were remembered as negative aspects by 7 tourists, while 9 individuals answered that Modernization and commercialization were an unpleasant experience. Finally, Early commoditization, Regional disparity and Gypsy community were mentioned as a negative aspect by 2 tourists.

The graphical analysis of correspondence (Figure 3) used the keywords Positive atmosphere (Atmosphere like) in order to make an association with every Destination. The first vertical dimension makes an order of Destinations, locating those places with similar features near one another. It is clear that two Destinations like Záhoří and Pulečný are isolated with respect to the other Destinations, because they both have particular 
Figure 1 Frequency diagram with concepts of atmosphere like

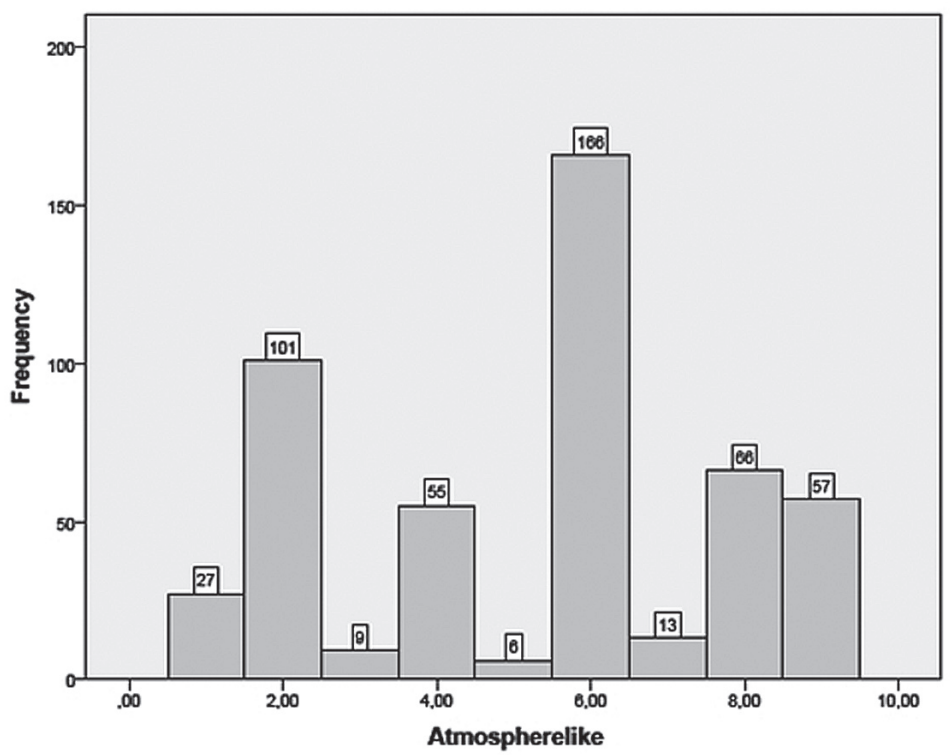

Source: authors' research (2013)

Figure 2 Frequency diagram with concepts of atmosphere dislike

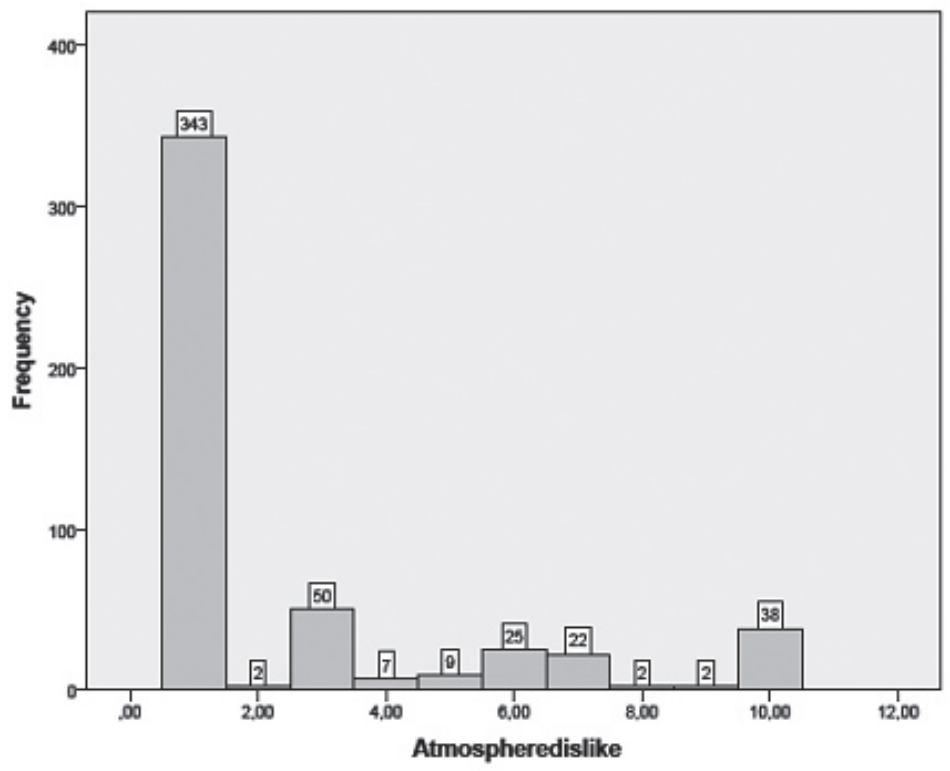

Source: authors' research (2013) 
Figure 3 Correspondence analysis: atmosphere like

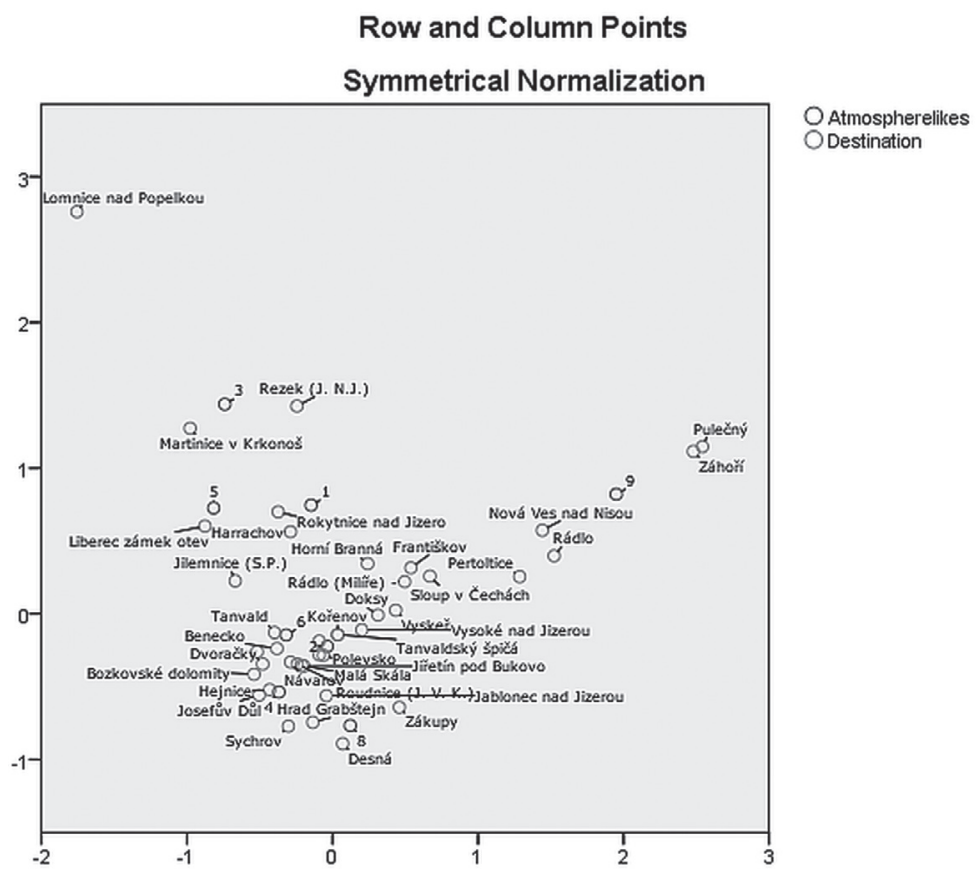

Source: authors' research (2013)

features in "Active approaches of local people to tourism". The localization of both Destinations on the plot indicates that these points in vertical and horizontal axes have generally higher values.

Other Destinations with equal situation are Nová Ves nad Nisou and Rádlo, where the visitors enjoyed the tourist services with a positive reponses during cultural events. This feature makes both Destinations different from others, so they are separated graphically in vertical and horizontal axes. Some Destinations such as Jiřetín pod Bukovou, Návarov, Malá Skála and Roudnice (Jestřábí v Krkonoších) have demonstrated a trend of clustering on the plane and there appear. A second agglomeration is formed by Dvoračky, Trojmezí and Bozkovské dolomity. Sychrov and Grabštejn are closely located as well. Another kind of cluster is formed by Hejnice and Josefův Důl, most likely because these places have Cultural monuments and Cultural landscape. Polevsko, Doksy and Vyskeř are plotted very closely, because the tourists characterized these places by Traditions, Customs, and Cultural activities. These Destinations were classified by participants as appreciated destinations in rural Cultural heritage (churches, rural buildings and rural handcrafts). Finally, Tanvaldský Špičák, Pulečný, Kořenov and Nová Ves nad Nisou are in the cluster of Tourist services for good quality, Active approaches of local people. According to tourist opinion, these seem to be tidy destinations. There are some destinations that 
were plotted separate from the rest of the destinations. The principal examples are Lomnice nad Popelkou, Rezek (Jablonec nad Jizerou) and Martinice v Krkonoších.

The distribution of points in both axes gives additional important information in relation to the individual destinations. It's observed that Lomnice nad Popelkou is closely related to Sport activities, because there is a track used for ski jump. In places like Rezek (Jablonec nad Jizerou), Lomnice nad Popelkou and Martinice v Krkonoších the participants mentioned the connectivity and frequency of the public Transportation. Liberec revealed that its principal attraction is the landscape of the local community, while Jablonec nad Jizerou and Sloup v Čechách were associated with aspects of its Tourist services. Some topics, such as the existence of Cultural monuments, were the main attractions in Hejnice. In Sychrov the Early commoditization is important, which is why it received low number of tourists and authenticity of rural area. The principal attractive in Tanvaldský Špičák is the Natural environment. It's important to say that the topic of Sport activities is scarcely named by tourists, and this reason explains why the allocation of this topic is low in respect to the others.

A similar analysis was performed in order to connect the destinations with the negative opinion of tourists (Figure 4). This exercise could be useful to capture possible deficiencies detected for each destination. There are possible problems associated, specifically, to any destination. Some problems of infrastructure were detected in Jablonec

Figure 4 Correspondence analysis: atmosphere dislike

\section{Row and Column Points}

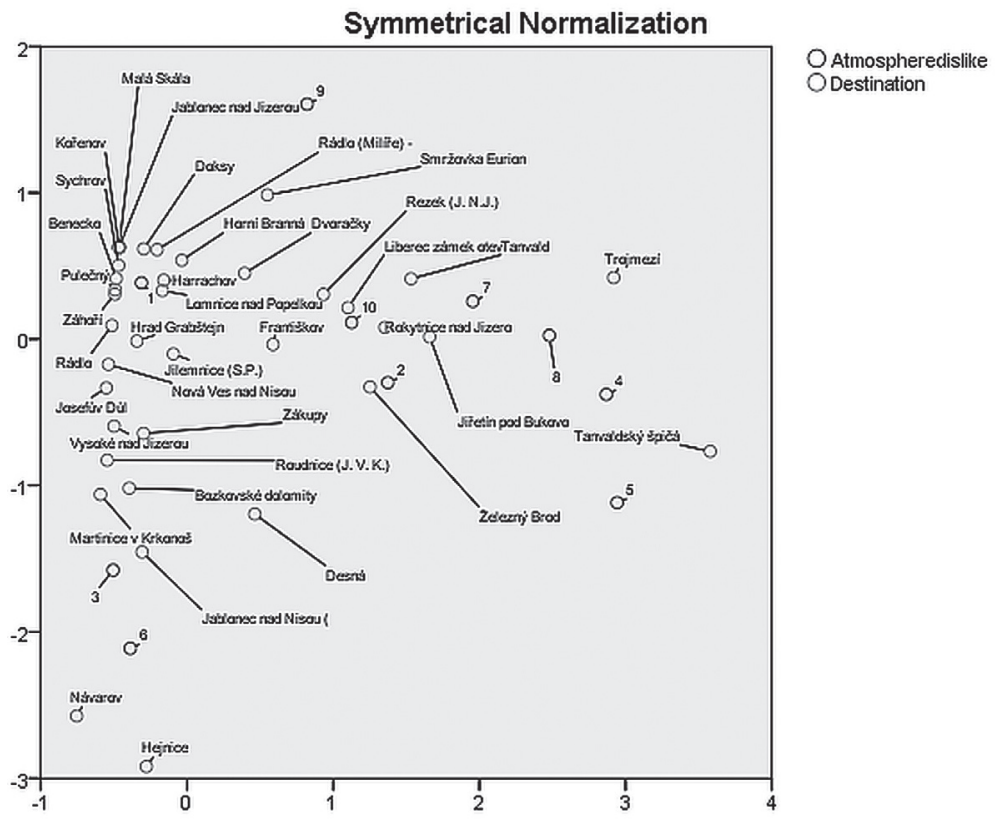

Source: authors' research (2013) 
nad Nisou, while some problems of Developed destruction were detected in Tanvald. Rokytnice nad Jizerou and Jiřetín pod Bukovou possess aspects of Developed commoditization. Liberec is plotted in a central place with respect to Developed commoditization and Developed destruction. For example, the castle has not been sufficiently maintained and the owner is going to sell to unknown buyer, so it generates a threat of abandonment of this Cultural monument.

Finally, in an analogue way, some topics were incorporated as options in positive and negative opinion, to allow visitors to express their impressions depending on the experience with respective topics. An example is Železný Brod where some participants recognized a negative aspect of the Early process of commoditization. It's important to note that in Negative atmosphere (Atmosphere dislike), a high number of destinations were agglomerated near the option of no response, which means that an important number of visitors were satisfied at these destinations. In order to handle the data and to find patterns in the categories, multiple correspondence analyses were performed. The authors combined some variables with the goal to detect the way in what model makes a discrimination of data. The results of these combinations were: Reasons of the tourist's visits in selected Destinations, Age, Gender and Nationality and Security of family background in destinations.

\section{Multiple analyses}

The joint plot of category points quantifies each variable and locates its categories according to the relationship between them. It is observed that the variable "destination" recognizes important differences across its categories, and plots some destinations far away from the rest. This tendency indicates that "Destination" is highly discriminated either on dimension 1 and dimension 2. This is understandable because "Destination" is the variable with the largest range of categories.

Differing from precedent, variable Business tourists show relative differences between categories that locate separately along the first dimension, but the differences are not as prevalent second dimension. Sightseeing/interest is a variable that has a high discrimination horizontally, but a low discrimination vertically. In regard to the Cultural experience, this variable was discrimination in both axes. Finally the variable that has the lowest discrimination is Education. Following education, the next lowest is Shopping and Social engagement.

The multiple correspondence analysis (Figure 5) allows association in similar categories and allows the categories to be plotted in closer relation. In observation to the joint plot of category points, some destinations are associated with categories that characterize its attributes. Hejnice and Františkov are observed with Sightseeing/interest for Cultural monuments and Cultural tourism. Relaxation/timeout has been enjoyed by tourists at Harrachov. For tourist that enjoyed the Special events, Sloup v Čechách and Pulečný are very interesting places. 
Figure 5 Reasons of visits

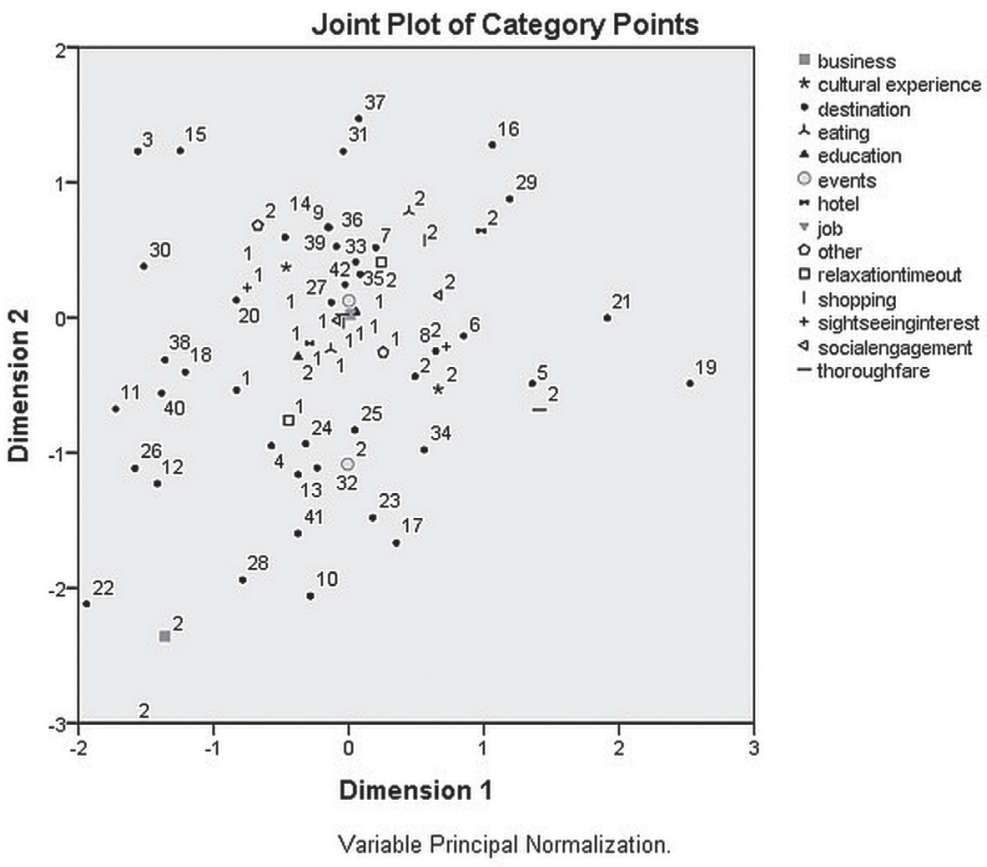

Source: authors' research (2013)

The correlation matrix (Figure 6) exposes the degree of association between the variables and the mathematical sign represents the sense of the relations between reasons of tourism in destinations. According to the expressions of tourists, it was detected that the highest correlation was generated between Cultural experiences and Sightseeing/interest. It indicates that tourists prefer Sightseeing/interests the next preferred Cultural experiences was expositions in museums or in castles, theatres and traditional activities. After this, it's observed that the second highest correlations were settled across the variables of Hotel, Eating and Relaxing/timeout. This means that the combined reasons of their chosen accommodation, Eating and Relaxing during their visit in destinations were a combination of these variables. An important correlation between Education and Cultural experience was also detected. People, who made a cultural journey, intended these travels as an instructive and educational experience. There is another special correlation between Hotel and Sightseeing/interest. It means that visitors was looking for interests of destinations, which is closely linked with their purpose of the visit being sightseeing and on order to do so, they stayed overnight at their accommodation (variable Hotel). Another important correlation was observed between Thoroughfares and Eating. It can be deduced from this correlation that some people stopped at certain places in order to take the food to eat later and continued their tour. It was also observed also that the reason Eating is associated with Other 


\begin{tabular}{|c|c|c|c|c|c|c|c|c|c|c|c|c|c|c|c|c|}
\hline ләчһо & 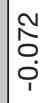 & $\begin{array}{l}\infty \\
0 \\
0 \\
0 \\
0 \\
1\end{array}$ & $\begin{array}{l}\infty \\
0 \\
0 \\
0 \\
\\
1\end{array}$ & $\begin{array}{l}\hat{1} \\
0 \\
0 \\
0\end{array}$ & $\begin{array}{l}1 \\
0 \\
0 \\
0 \\
0\end{array}$ & $\begin{array}{l}\infty \\
\infty \\
\infty \\
0 \\
1\end{array}$ & 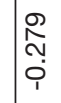 & $\frac{\bar{m}}{\bar{m}}$ & 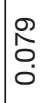 & 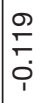 & $\frac{\infty}{0}$ & $\frac{m}{m}$ & $\begin{array}{l}\infty \\
0 \\
0 \\
0 \\
0 \\
1\end{array}$ & - & 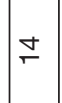 & ঙ্ণিণ \\
\hline sұuәлә & 苋 & $\begin{array}{l}0 \\
\text { Oे } \\
0 \\
0\end{array}$ & 용 & ষे & 응 & 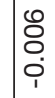 & 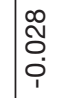 & $\frac{\text { g }}{\square}$ & 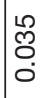 & $\begin{array}{l} \\
0 \\
0 \\
0 \\
\end{array}$ & $\begin{array}{l}\text { 苋 } \\
0 \\
0 \\
0 \\
1\end{array}$ & $\frac{9}{9}$ & - & $\begin{array}{l}\infty \\
\infty \\
0 \\
0 \\
0 \\
1\end{array}$ & $\stackrel{m}{\longrightarrow}$ & $\begin{array}{l}\mathscr{6} \\
6 \\
0 \\
0 \\
0\end{array}$ \\
\hline әлејч6nодочł & 듬 & 合 & 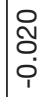 & ठ̊ & ஜ뭉 & \begin{tabular}{l}
0 \\
$\varnothing$ \\
$\varnothing$ \\
\hdashline \\
\end{tabular} & $\frac{\bar{m}}{\overline{0}}$ & $\begin{array}{l}0 \\
\\
O \\
0 \\
0\end{array}$ & 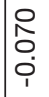 & $\begin{array}{l}\text { L } \\
\stackrel{2}{0} \\
\stackrel{0}{0} \\
0\end{array}$ & $\begin{array}{l}\hat{8} \\
\text { o } \\
\text { i }\end{array}$ & - & $\frac{\mathscr{m}}{\check{m}}$ & $\mid \begin{array}{l}m \\
\\
\\
\\
1\end{array}$ & $\cong$ & 㑒 \\
\hline ұnoәш!̨uo!łехе|ә & 合 & 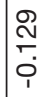 & 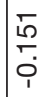 & ठु & б. & 尺్. & 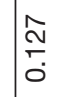 & $\begin{array}{l}\infty \\
\ddot{O} \\
\varnothing \\
0\end{array}$ & 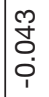 & مָ & - & 各 & $\begin{array}{l}\text { L } \\
\text { L̊ } \\
0 \\
0 \\
\end{array}$ & $\frac{\mathscr{0}}{0}$ & $\mp$ & ז. \\
\hline ІәңОЧ & ల్ల & 萬 & $\begin{array}{l}0 \\
\mathscr{O} \\
0 \\
\end{array}$ & $\frac{8}{0}$ & م્o & 㣽 & 菖 & $\begin{array}{l}2 \\
\stackrel{2}{0} \\
0 \\
0\end{array}$ & $\begin{array}{l}0 \\
0 \\
0 \\
0 \\
1\end{array}$ & - & 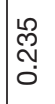 & $\begin{array}{l}\stackrel{n}{0} \\
\stackrel{0}{0} \\
0\end{array}$ & $\begin{array}{l} \\
0 \\
0 \\
0 \\
i\end{array}$ & $\begin{array}{l}0 \\
\\
\\
\\
1\end{array}$ & 으 & $\begin{array}{l}\mathscr{0} \\
0 \\
0 \\
0\end{array}$ \\
\hline uo!łeonpə & $\begin{array}{l}0 \\
\\
0 \\
0 \\
0\end{array}$ & $\begin{array}{l}0 \\
\\
0 \\
0 \\
0 \\
\end{array}$ & 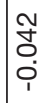 & 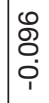 & $\begin{array}{l}\mathcal{M} \\
\hat{0} \\
0 \\
i\end{array}$ & वृ & $\begin{array}{l}\text { 竎 } \\
\text { o } \\
\text { i }\end{array}$ & $\frac{\pi}{0}$ & - & $\begin{array}{l}0 \\
0 \\
0 \\
0 \\
1\end{array}$ & 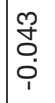 & $\begin{array}{l}\text { P } \\
0 \\
0 \\
0 \\
\text { i }\end{array}$ & $\begin{array}{l}0 \\
\tilde{O} \\
0 \\
0\end{array}$ & $\begin{array}{l}\Omega \\
\stackrel{\Omega}{0} \\
0 \\
0\end{array}$ & の & $\begin{array}{l}\infty \\
\infty \\
\infty \\
0 \\
0\end{array}$ \\
\hline 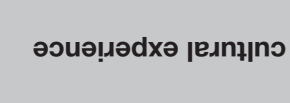 & 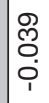 & $\begin{array}{l}\bar{m} \\
\text { Oִ } \\
0\end{array}$ & $\begin{array}{l}\bar{n} \\
10 \\
0 \\
0\end{array}$ & 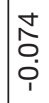 & 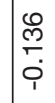 & ه্ & \begin{tabular}{l}
$\stackrel{\infty}{\sim}$ \\
\multirow{\sigma}{0}{}
\end{tabular} & - & ס. & 吕 & $\begin{array}{l}\infty \\
\ddot{\infty} \\
0 \\
0\end{array}$ & $\begin{array}{l}0 \\
\mathscr{O} \\
0 \\
0\end{array}$ & 守 & $\begin{array}{c}\bar{m} \\
\bar{c} \\
\overline{1}\end{array}$ & $\infty$ & 웅 \\
\hline ұsәдәłu!/6u!əәsł46!S & 듬 & 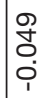 & 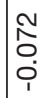 & ¿َ & ס̊ & 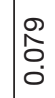 & - & 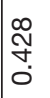 & $\begin{array}{l}\text { Oे } \\
\text { Oִ } \\
\text { i }\end{array}$ & 足 & 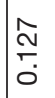 & 产 & 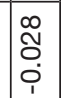 & \begin{tabular}{|l|} 
\\
$N$ \\
$N$ \\
0 \\
1
\end{tabular} & $\sim$ & గొ \\
\hline $\begin{array}{r}\text { ұиәшәбебиә } \\
\text { ןе!юоร }\end{array}$ & $\begin{array}{l}0 \\
0 \\
0 \\
0 \\
0 \\
1\end{array}$ & 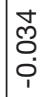 & 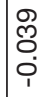 & $\begin{array}{l}\Omega \\
\infty \\
0 \\
0 \\
0\end{array}$ & 仓̊ & - & 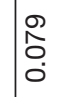 & $\begin{array}{l}0 \\
\\
\\
0\end{array}$ & 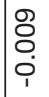 & $\begin{array}{l}\text { 尺ి } \\
\text { Oọ } \\
\text { ị }\end{array}$ & 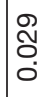 & $\begin{array}{l}0 \\
\& \\
0 \\
0 \\
i\end{array}$ & $\begin{array}{l}0 \\
0 \\
0 \\
0 \\
1\end{array}$ & $\mid$\begin{tabular}{l}
$\infty$ \\
$\infty$ \\
\hdashline \\
0 \\
1 \\
1
\end{tabular} & 0 & ஜֶ. \\
\hline 6u!łeə & $\frac{m}{0}$ & 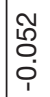 & $\begin{array}{l}\overline{0} \\
\\
\\
\end{array}$ & \begin{tabular}{l}
$\infty$ \\
$\infty$ \\
\hdashline \\
0
\end{tabular} & - & $\begin{array}{l}\hat{\theta} \\
0 \\
0\end{array}$ & ণ̊ & 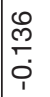 & 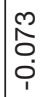 & 尽 & ס्: & סֶ & $\begin{array}{l}10 \\
0 \\
\\
0\end{array}$ & $\begin{array}{l} \\
0 \\
0 \\
0 \\
\end{array}$ & م & 尺̊. \\
\hline 6u!ddoys & ठ্ & 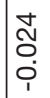 & 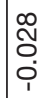 & - & 足 & 足 & 守 & 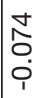 & $\begin{array}{l}0 \\
\\
\\
\\
\end{array}$ & 웅. & 总 & ষ্ণ & $\mid \begin{array}{l}0 \\
0 \\
0 \\
0\end{array}$ & 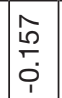 & $\nabla$ & ָָ \\
\hline qo! & 各 & 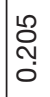 & - & 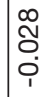 & $\begin{array}{l}\overline{8} \\
\dot{0} \\
1\end{array}$ & 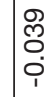 & 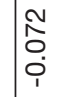 & $\begin{array}{l}\bar{n} \\
0 \\
0 \\
1\end{array}$ & $\begin{array}{l}\text { Y } \\
\text { Oִ } \\
\text { Oִ }\end{array}$ & \begin{tabular}{l}
0 \\
\hdashline \\
\hdashline \\
\\
\end{tabular} & $\frac{5}{5}$ & 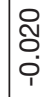 & 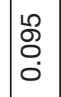 & $\begin{array}{l}\infty \\
0 \\
0 \\
0 \\
1 \\
\end{array}$ & $m$ & مُ \\
\hline ssəu!̣snq & $\begin{array}{l}\infty \\
\tilde{ల} \\
0 \\
0\end{array}$ & - & 定 & 壱 & $\begin{array}{l}\tilde{N} \\
\tilde{D} \\
0 \\
0 \\
i\end{array}$ & 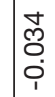 & $\mid \begin{array}{l}\text { Pि } \\
\text { Oִ } \\
\\
\end{array}$ & 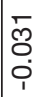 & 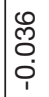 & $\begin{array}{l}-5 \\
0 \\
0 \\
\\
1\end{array}$ & 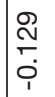 & $\begin{array}{l}1 \\
0 \\
0 \\
0 \\
1\end{array}$ & $\begin{array}{l}0 \\
\dot{0} \\
\dot{0} \\
\dot{0}\end{array}$ & \begin{tabular}{l|}
$\infty$ \\
0 \\
0 \\
0 \\
0 \\
1
\end{tabular} & $\sim$ & 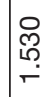 \\
\hline uo!̣eu!̨sәp & - & $\begin{array}{l}\infty \\
\check{ల} \\
0 \\
0\end{array}$ & 욤 & छ̈ & 商 & 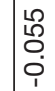 & 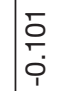 & $\begin{array}{l}\text { ஜ్ } \\
\text { ర్ } \\
\text { ị }\end{array}$ & \begin{tabular}{l}
0 \\
\\
0 \\
0 \\
\hdashline \\
1
\end{tabular} & ஜூల్ & $\begin{array}{l}\hat{8} \\
0 \\
i\end{array}$ & 음 & 艺 & $\begin{array}{l}\mathbb{N} \\
\tilde{O} \\
0 \\
1\end{array}$ & - & $\begin{array}{l}\mathscr{N} \\
\infty \\
\infty \\
\\
\end{array}$ \\
\hline & 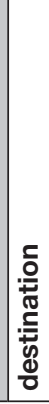 & 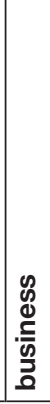 & 응 & \begin{tabular}{l} 
음 \\
\hdashline$\frac{0}{0}$ \\
$\frac{2}{0}$ \\
$\frac{2}{\infty}$
\end{tabular} & D & 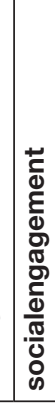 & 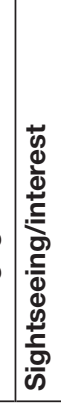 & 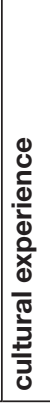 & 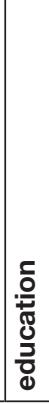 & 离 & 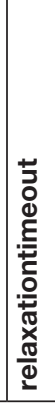 & 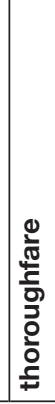 & 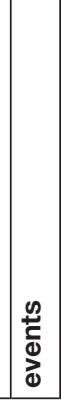 & 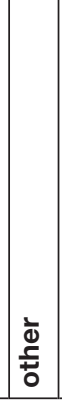 & 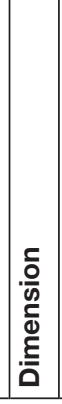 & 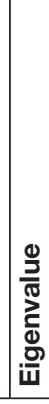 \\
\hline
\end{tabular}


situations such as Shopping and Special events was because tourists focus was shopping or the special events.

In regard to negative correlations, some variables were associated in an interesting way. The highest negative correlation was detected between the motivations Sightseeing/interest and „Other“. This indicates that there are two kinds of excluding interest: people who are focused on a specific attraction and do not look for diversity. The "Other" reason encompasses different motivations as race ski, skiing, relax, cottage, nature walking, museums, holidays, recreation, party, waterfall etc. Finally, if the tourists were travelling for Business, they didn't come to these destinations in order to relax.

In order to determine which variables are dominant with in each dimension, it's important to plot a graph of discrimination (Figure 7), that shows the variance of each variable represented on each dimension. The graphic depiction of discrimination contributes to the understanding of the criteria used by the model for depicting the categories on the two dimensional plane. Firstly, it is evident that the variable Destination discriminates highly on both dimensions. A variable such as Sightseeing/interest has a high discrimination on horizontal axis, but a low discrimination on vertical axis. Finally Relaxation/timeout discrimination has an important magnitude in the vertical direction. Shopping, Business, Thoroughfare, Social engagement and Education are variables that show a very low discrimination both in dimension 1 and in dimension 2.

Figure 7 Discrimination measures of variables reasons and destination

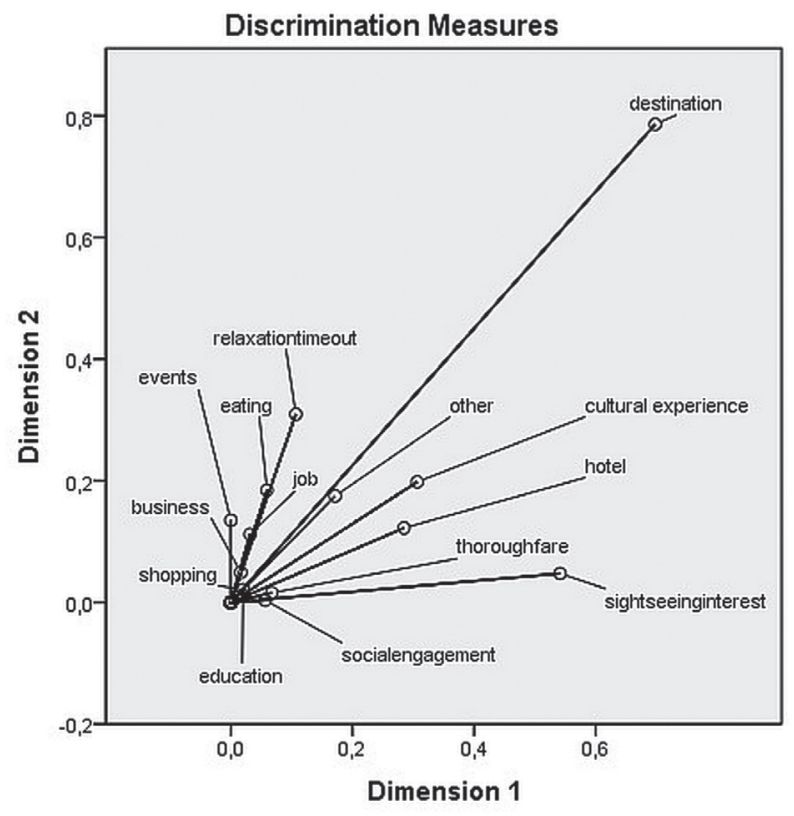

Variable Principal Normalization.

Source: authors' research (2013) 
A comparison between Plot of joint categories and graph of discrimination measurement confirms that the variable Destination predominates in both horizontal and vertically discrimination and that its categories are quite separated in the Plot of categories.

Other analysis was applied to combine four variables and the relations between their categories were observed. The four variables included were: Destination, Origin of tourists, and Stay of visit and Term of visit (Figure 8). The variable stay of visit regarding to how many days were dedicated to the visit at each destination (1 night more/ or less). The question about the term of visit had four options to response: holidays, weekends, weekly, special events and the other.

Figure 8 The stay of tourists

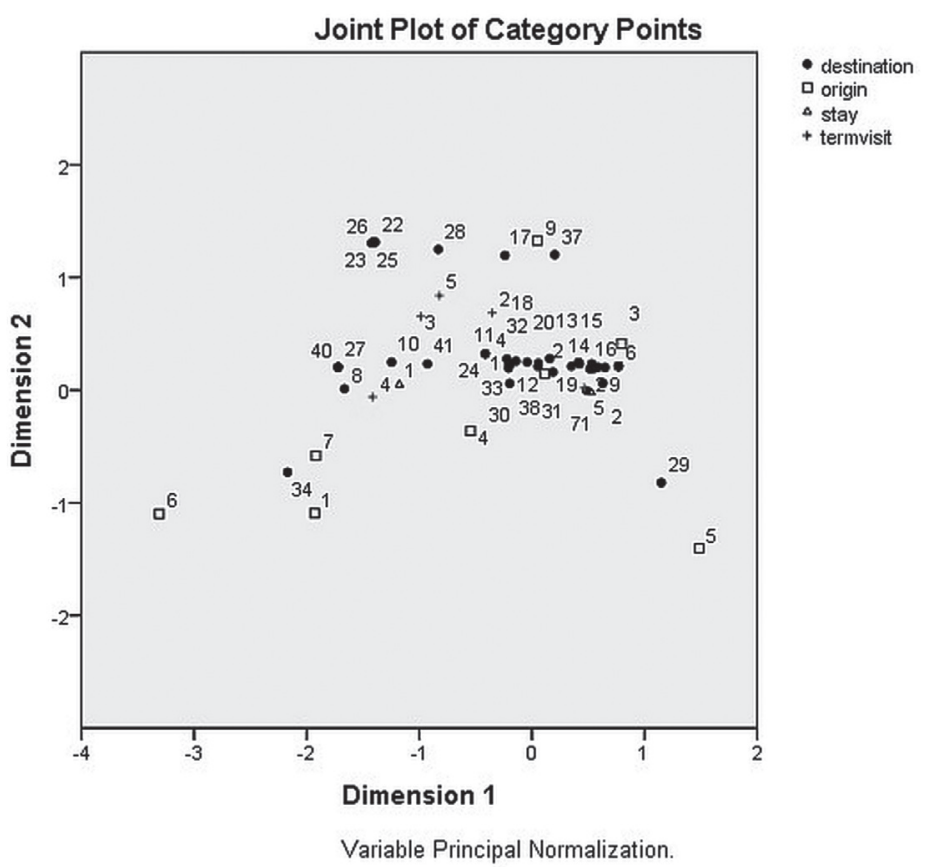

Source: authors' research (2013)

According to graph of points categories some agglomeration were depicted. The combination of a stay for one night or less with weekend visit, were observed in Jablonec nad Jizerou, Jiřetín pod Bukovou, Benecko and Grabštejn. In most cases the tourists visited following destination weekly: Nová Ves nad Nisou, Pertoltice, Pulečný, Rádlo and Raspenava. Tourists were in Harrachov, Bozkovské dolomity, Dvoračky, Jiřetín pod Bukovou, Josefův Důl, Malá Skála and Horní Branná for more than one night. In the destinations of Doksy, Polevsko and Martinice v Krkonoších the tourists spent an unspecified amount of time on the visit. German tourists have been visiting Rokytnice nad Jizerou, 
Jablonec nad Nisou and Smržovka. French tourists prefer to visit Dvoračky, Františkov, Tanvald, Kořenov and Jiřetín pod Bukovou.

A final combination of the variables was performed in order to compare Destination, Family background and Security (Figure 9). It's observed that for such comparison some destinations are identified as different in comparison with others, specifically Desná and Polevsko. In the same context, the category "divorced" reveals important differences with the rest of Family backgrounds, because it is an outlier along the horizontal axis.

Figure 9 Security of family background in destinations

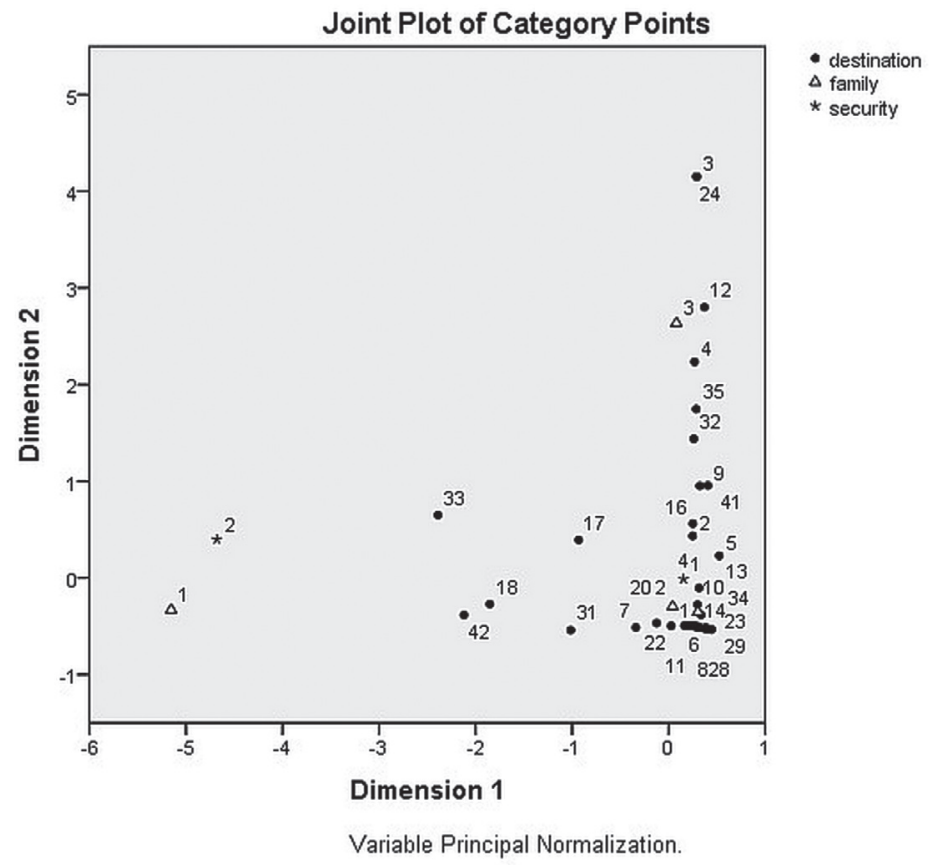

Source: authors' research (2013)

\section{Discussion}

Discussion (Mason, 2003) focuses on the location of tourist's destinations. Major impacts tended to be noted in destinations and may be felt strongly by the residential population. Hence, there is a major need for planning and managing of tourism destinations. A variety of important factors contributed to the development of tourism during the $19^{\text {th }}$ and $20^{\text {th }}$ century. Mason (2003) suggested five major reasons for the growth of tourism. Three of the reasons can be applied to the research completed for Liberec region, as can be seen from the commentaries from 52 of the participants. These reasons are: Improvements in transport technology (which leads to cheaper and more accessible travel etc.), 
Changing perceptions of the environment (237 destinations that were once viewed as hostile, are now seen as attractive by tourist's) and Increasing desire to travel (according to these motivations, 92 tourists mentioned improvement in education, 227 mentioned created interest in attractive destinations and 29 mentioned business travels). The American researcher Plog developed ideas on the psychology of tourists that were published in 1973. An important contribution from Plog's ideas was the notion of allo- and psychocentric types of tourist. He argued that there are psychological types (psycho-centric) that don't like unfamiliar environments or cultures, so when they select a holiday they will seek the familiar environments or cultures.

In this case of the Liberec region were assumed $88.8 \%$ of psycho-centric tourists (family, friends and tour group), who seek the familiar type of tourism in selected destinations. On the other hand, it could be concluded, that the allo-centric tourists represented $11.2 \%$ of total (alone, colleagues and other). The results argue in Plog's term, that psycho-centric tourist's will not travel far from the local environment/region to take a holiday. The results confirm that this type of tourists was accommodated near the observed destinations.

However, allo-centric tourists in the Liberec region cannot be classified in Plog's terms, because only 20 tourists from a total amount of 128 allo-centric tourists were overnight near the desired destinations. It means that they travelled from their residence to attractive destinations and a majority of them had residence near the research area. Plog suggested that the majority of tourists were neither fully psycho-centric nor fully allo-centric in relation to their holiday destination choices. In terms of his theory, the great majority of tourists are located close to a mid-point between the extremes of psycho-centric and allo-centric. Nevertheless, Plog pointed out that in relation to their selected holiday destination, the majority of tourists seek the familiar environment and prefer to travel shorter distances to get there. Finally we can conclude similar results in the case of Liberec, because of 292 tourists out of the participants that they travelled in the company of families and friends. Contrasting Plog's term, 152 of the participants stayed overnight. From this point of view, it can be said, that distance from the searched area was further.

Plog's theory can be closely linked to the psychological makeup of tourists, and Cohen's ideas can be related to the behavior of tourists. Cohen (1972) developed a typology of tourists in which there was a fourfold classification: organized mass tourists, individual mass tourists, explorers and drifters. The same results were concluded in this case as in psycho-centric (organize mass tourists $88.8 \%$ ) and allo-centric tourists (individual mass tourists $11.2 \%) .{ }^{1}$ Some differences can be observed between the two theories.

1) In terms of international tourism, organized mass tourism includes the organized travels by tour agencies, but in the context of rural tourism it was decided to use this axial terminology, because the Liberec region is situated on the borders with two foreign countries. So the foreign tourists are included in this research. Consequently in this context, the organized mass tourists means the organized groups in the same way of travel agency and it means also the organized groups carried by tour agencies. It was decided to use this theoretical framework of Cohen and Plog, because the whole field research is based on the perceptions, meanings and expectations of visitors that fulfilled the psychological makeup or behavior of tourists according these autors. 
According to Cohen, the organized mass tourists (ORMT) take a packaged holiday (travel, accommodation and food are also arranged in advance of the trip). In the case of Liberec, it was observed that food had provided 62 ORMT and accommodation had ordered 47 ORMT from the total amount of 292 ORMT. On the other hand, Cohen sorts groups of individual mass tourists (IMT), who use the same facilities as the organized mass tourists, but make more individual decisions about their tourist activity. In selected destinations, more than 138 IMT were surveyed, and only 25 of them had ordered food before their travel and only one had reserved accommodation. In the searched destinations of Liberec region there were three explorers and 14 drifters (five of them stayed overnight). Cohen (1972) said that explorers arrange their own visit/trip. They went 'off the beaten track' and they wished to meet locals. The drifter shuns contact with other tourists and 'goes native' by staying with locals. He/she stays longer than most tourists and don't regard himself/herself as a tourist. It is possible to combine the key ideas of Cohen with those of Plog. In this way, it can be suggested that the majority of Cohen's 'mass tourists' and 'independent mass tourists' are likely to conform to Plog's category of psycho-centric tourists. The theories of both Plog and Cohen also suggest that few tourists would come into contact with more distant and 'different' cultures. The preceding discussion may imply that host communities are passive recipients of tourists. This is not necessarily the case, because only 12 of psycho-centric tourists were dissatisfied with Unwillingness of local people, and 36 were dissatisfied with Lack of development. There are many examples, particularly in developed countries and increasingly in the developing world, where local residents in a tourist destination are actively involved in the provision of tourism and also in its planning and management (Mason, 2003). By the late 1990s, there was a groundswell of opinion that communities should be involved actively in planning of tourism (Middleton \& Hawkins, 1998). This can be assumed with Mason (2003) and Middleton and Hawkins (1998) and the 25 responses of psycho-centric tourists and their satisfaction with Tourist services and Active approaches of local people in tourism. However, this is not a particularly recent development in the Liberec region. According to commentaries in this research, it can be said that 119 tourists recommended better approaches in activities of local communities in the Liberec region, meaning that the local communities can be a key player (Murphy, 1985) in the process of planning and managing tourism.

\section{Conclusion}

Graphic analysis applied and statistical tools can contribute to make a typology of tourists that visited some analyzed destinations. Consequently, some clues can be detected in terms of their motivations and reasons for visit particular attractions. It can be observed that people of intermediate age (30-50) prefer destinations such as Josefův Důl, Malá Skála, Návarov and Trojmezí. Older tourists (+50 years) were plotted near destinations of Vyskeř, Jablonec nad Nisou, Raspenava and Polevsko. Young people identified with Dvoračky, because there is the environment for Sport activities. Other obvious in- 
dication is that when people start a trip with the purpose of Business, an entertainment journey is ruled out. The majority of destinations were perceived as safe. Some of them were plotted related to each category of Family background. The category "pensioners" was located close the two destinations Jablonec and Nisou and Doksy. The category "single“ was plotted very close to Grabštejn and Sychrov. Finally married couples were very attracted to Nová Ves nad Nisou. The Liberec region is a privileged place because of its Natural landscape and Cultural and human richness. Each destination included in the research, has a specific resource to be exploited as a commodity for tourism. From the research of atmospheres it can be concluded that visitors greatly appreciate the peaceful environment and the Natural landscape of the region. Meanwhile, negative aspects are related mainly to Lack of Infrastructure and Developed commoditization. The elaboration of the article included ground research that asked tourists. The vast majority of the visitors were Czech and only a small number were foreigners, most of them Polish. It is a good reason to reinforce the advertising and promotion of the region outside of the Czech Republic. Special focus can be put on the southern region of neighboring Germany.

Figure 10 Gender, age and origin of tourists

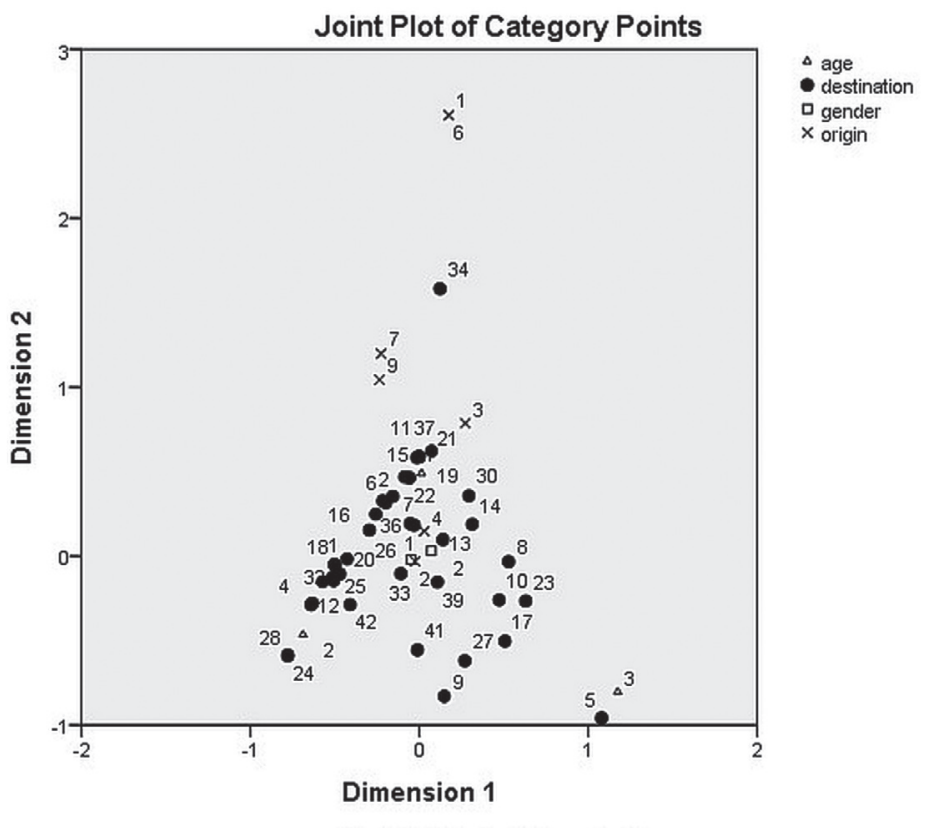

Variable Principal Normalization.

Source: authors' research (2013) 
In general, tourists felt a sensation of safety in the Liberec region and most of them didn't express any unpleasant commentaries. From the plots of categories, profiles of tourists can be built taking into account the Age, Nationality, Family background, etc. Some destinations can focus its attention to a specific group of people, reinforcing its aim with the features of each place for example, Sport activities, Cultural monuments, Rural landscape, Traditions and customs. The statistical results confirmed fundamental features of the observed destinations that match with general opinions of visitors. Lomnice nad Popelkou, Harrachov and Rokytnice nad Jizerou have a high tourist potential in Sport activities that can be used as a tool for rural sustainability and local development with influence of the whole region. Destinations such as Sychrov, Hejnice, Grabštejn, Pertoltice and Sloup v Čechách demonstrated to be attractive for tourists that are looking for Cultural monuments and Cultural rural tourism. Although, with the lack of a public promotion it could be suggested that local providers and make an effort in terms of advertising. Some tourists revealed to have a specific profile according their responses. A few of them assumed the visits as educational and instructive experiences, while others visited places with an entertainment purpose. Some visitors had business meeting and job activities as the objectives. Crowds of people can be used as a market for regional products and tourist services which represented the complementary supply of tourist services in observed destinations. It also means that their increasing potential to be an attractive destination in the Liberec region. A practical strategy for local authorities in all destinations consists of recognizing the profile of the tourist that visited their local specific attractions, and identify the comparative advantage of municipality in terms of environment, rural landscape, historical and cultural monuments, etc. In those terms, a match between supply and demand can be made and some advertising campaign can be aimed to the specific group in question.

\section{References}

Chadwick, R. (1987). Concepts, definitions, and measures used in travel and tourism research. In J. R. B. Ritchie \& C. Goeldner (Eds). Travel, Tourism and Hospitality Research: A Handbook for Managers and Researchers. New York: Wiley.

Cohen, I. (1972). Towards a sociology of international tourism. Social Research, 39, 164-182.

Crompton, J. (1979). Motivations for pleasure vacations. Annals of Tourism Research, 6(4), 408-424.

Crompton, J., \& McKay, J. (1997). Motives of visitors attending festival events. Annals of Tourism Research, 24(2), 425-439. DOI: 10.1016/S0160-7383(97)80010-2.

Fuchs, M., \& Höpken, W. (2011). E-Business horizons in the tourism industry - Challenges for research and practice In K.L. Sidali et al. (Eds.), Food, Agri-Culture and Tourism: Linking local gastronomy and rural tourism: interdisciplinary perspectives (pp. 140-160). Berlin: Springer-Verlag Berlin Hidelberg.

Hall, D. Kirkpatrick, I., \& Mitchell., M. (2005). Rural tourism and sustainable business. Toronto: Channel View Publications.

Harrill, R., \& Potts, T. (2002). Social psychological theories of tourist motivation: exploration, debate and transition. Tourism Analysis, 7(2), 105-114. 
Hunt, J. (1971). Image-A factor in Tourism. Unpublished. Doctoral Dissertation. Colorado: State University, Fort Collins, CO.

Iso-Aloha, S. (1980). The Social-Psychology of Leisure and Recreation. Iowa: Brown.

Jambu, M. (1983). Cluster analysis and data analysis. Amsterdam: North-Holland.

Long, N. (2001). Development sociology: actor perspectives. London: Routledge.

Mason, P. (2003). Tourism impacts, Planning and Management. Oxford: Elsevier.

Matthieson, A., \& Wall, G. (1982). Tourism: Economic, Social and Environmental Impacts. London: Longman.

Mayo, E. (1973). Regional Images and Regional Travel Behavior, Proceedings of the Fourth Annual Travel Research Association Conference. pp 211-217. Salt Lake City, Utah.

Middleton, V. T. R., \& Hawkins, R. (1998). Sustainable Tourism: A Marketing Perspective. London: Butterworth-Heinemann.

Mitchell, C.J.A., \& de Waal, S.B. (2009). Revisiting the model of creative destruction: St. Jacobs, Ontario, a decade later. Journal of Rural Studies, 25 (1), 156-167. DOI: 10.1016/ j.jrurstud.2008.09.003.

Murphy, P. (1985). Tourism: A Community Approach. London: Methuen.

Pearce, P. (1993). Fundamentals of tourist motivations. In D. Pearce, \& R. Butler (Eds.), Tourism Research: Critiques and Challenges (pp. 113-134). London: Routledge.

Plog, S. (1973). Why destination areas rise and fall in popularity. Cornell Hotel and Restaurant Administration Quarterly, 12, 13-16.

Prosser, R. (1998). Tourism. In Encyclopaedia of Ethics, vol. 4, (pp. 373-401). Chicago, IL, Houghton Mifflin.

Raybould, M., Digance, J., \& McCullough, C. (1999). Fire and festival: authenticity and visitor motivation at an Australian folk festival. Pacific Tourism Review, 3, 201-212.

Regoli, F., Vittuari, M., \& Segrè, A. (2011). Policy options for sustainability. a preliminary appraisal of rural tourism in Romania: the case of Maramureş. In K.L. Sidali et al. (Eds.), Food, Agri-Culture and Tourism: Linking local gastronomy and rural tourism: interdisciplinary perspectives (pp. 41-54). Berlin: Springer-Verlag Berlin Hidelberg.

Ryan, C. (1991). Recreational Tourism. London: Routledge.

Ryan, C. (1997). The Tourist Experience. London: Cassell.

Scott, N., \& Cooper, CH. (2007). Network Analysis as a Research Tool for Understanding Tourism Destinations. In D. Airey, \& J. Tribe (Eds.), Developments in Tourism Research. Amsterdam: Elsevier.

Singhal, S., McGreal, S., \& Berry, J. (2013). Application of a hierarchical model for city competitiveness in cities of India. Cities, 31, 114-122. DOI: 10.1016/j.cities.2012.05.012.

Vriens, M. (1995). Conjoint analysis in marketing: developments in stimulus representation and segmentation methods. Netherlands: Labyrint Pub.

Youell, R., \& Wornell, R. (2005). Quality as a Key driver in Sustainable rural tourism businesses. In D. Hall, I. Kirkpatrick, \& M. Mitchell (Eds.), Rural tourism and sustainable business (pp. 227-235). Toronto: Channel View Publications. 